\title{
写像解析に基づく岩盤空洞周辺の塑性領域の 簡易推定法
}

\author{
蔣 宇静 ${ }^{1} \cdot$ 江崎哲郎 ${ }^{2}$ \\ ${ }^{1}$ 正会員 工博 九州大学助教授 工学部環境システム工学研究センター（テ812 福岡市東区箱崎 6-10-1） \\ ${ }^{2}$ 正会員 工博 九州大学教授 工学部環境システム工学研究センター
}

\begin{abstract}
著者らは，破壊後にひずみ軟化およびダイレタンシー挙動を呈する岩盤内に掘削した円形空洞の弾塑性挙動の 理論解析法を提案してきている1) 3). 本論文は，さらにそれを非円形断面の岩盤空洞に適用するための一簡易手 法 (写像解析推定法) を提案する.この方法は, 複素関数論の等角写像展開原理に基づき, 先に提案した円形空 洞の理論解から，非円形空洞の周辺岩盤内の塑性領域の発生やその広がりを直接に推定することができ，また， 複雑な弾塑性応力の解析過程が要らず，パソコン上でも迅速に解析できる特徴を有する.
\end{abstract}

Key Words : non-circular underground openings, plastic zone, mapping method, strain-softening behavior

\section{1.はじめに}

近年，産業社会の発展，都市化の促進などによって， 地殼の開発，特にエネルギー施設，大断面トンネル，さ らに地上空間の延長とした都市深部地下の開発利用が注 目を集めている，その中で，空洞の深度，断面は大きく なり，岩盤条件の良好でない位置での建設の機会も増加 の一途である.このような状況の中で，適切かつ安全な 岩盤内構造物の建設を進めるためには，開削による地下 空間の周辺岩盤の安定性を適切に評価できる解析方法の 確立が重要な課題の一つ之なっている，岩盤中に空洞が 構築されると，その周辺には，集中応力が誘起されるた め, 地山の強度が比較的に小さい場合, 周辺岩盤が塑性 破壊を生じる.塑性領域の広がりを予め判断することは, 支保工を事前設計評価する上で不可欠である.

岩盤空洞の塑性領域の評価に関する理論的研究として は, 円形空洞を対象としたものが多く, 弾性論や塑性論 に基づいたいくつかの手法が提案されている(4) 8).一方， 非円形空洞に関しては，ひずみエネルギー論に基づいた 棈円形空洞の安定解析9) や境界要素-特性曲線結合法の ような準解析的手法を用いた矩形空洞の解析 ${ }^{10)}$ な゙があ るが比較的少ない。これは, 幾何学的および力学的境界 条件のインプット面から言えば，円形に比べて空洞の断 面形状が複雑なほど，解析過程が複雑となり，理論上完 全に解けないこともあるためであろう。この場合，有限 要素法等による数值解析を行えば，塑性領域なざは容易 に求めることができるが, 解析には, 岩盤挙動を正確に 表現できる力学的モデルの定式化の困難さや，安定に影
響する各種要素の影響度を解明するのに相当に手間や費 用がかかったり，計算機の容量などの面で制約を受けた りすることが指摘されている.

一方, 現場の計測変位から, 岩盤空洞の周辺に発生し た塑性領域の大きさを逆に推定する方法も試みられてい $3^{11)-13)}$. それらは, 計測変位から地山中の引張りひず み分布 ${ }^{11), 121}$, または最大せん断ひずみ分布 ${ }^{(3)}$ を逆解析し, それらを岩の限界ひずみと比較することによって, 塑性 領域を推定する．これらの方法は，工事中の空洞の安定 状態を評価するには有用な知見を与えられるが，空洞掘 削による塑性領域の事前推定は非常に困難であり,また， 岩の限界ひずみの評価や，現場測点の配置と数の決定な ゼ，十分な配虑が必要であると思われる。

著者らは深部地下空洞の安定性評価之適切な支保設計 を行うために，ピーク強度以降のひずみ軟化特性および ダイレタンシー特性を考慮した力学的モデルを提案し, 円形空洞の弾塑性挙動の理論的解明を行ってきてい る1) 3)．本論文はさらに，著者らが提案した円形空洞の 理論解を非円形空洞の周辺岩盤に生じる塑性領域の事前 推定に適用するアプローチを示すものである．この手法 では，まず初期応力および岩盤材料の強度特性が同じ状 態での単位円孔（半径が1である円形空洞を指す）の周 りに生じる塑性領域を，先に提案した理論解析法によっ て求める. 次に，それらを非円形空洞の孔縁形状を表す 写像関数を用いて逆写像させることによって, 非円形空 洞の周辺岩盤に発生する塑性領域の規模を直接で近似に 評価する．このように得られた塑性領域の規模は，近似 的なものでありながら, 有限要素法による数值解析結果 


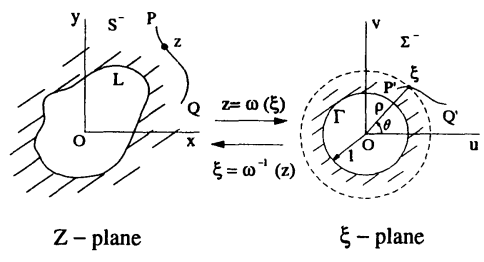

Fig.1 Mapping principle.

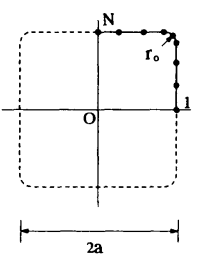

(a)

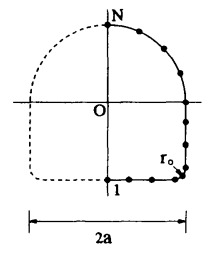

(b)

Fig.2 Cross-section boundary of opening.

との比較によって, よい一致性が検証された。

\section{2. 等角写像展開法}

\section{（1）基本原理}

非円形孔のある平板内の弾性応力を求めるには，従来 より, 複素関数論における等角写像展開法が利用されて きた。また, 破壊力学の分野においては, 任意形状孔の 近傍のき裂の応力拡大係数やき裂の干渉のような非線形 問題を研究するにも, 同法がよく取り上げられ, 多数の 研究結果が発表されている ${ }^{14}$.

等角写像展開法 ${ }^{15)}$ は Fig.1 のように, 次式に示す正則 関数

$$
z=\omega(\xi)
$$

によって, $z$-平面上の非円形孔境界 $L$ を $\xi$-平面上の単 位円 $\Gamma$ に, また孔の外部領域 $S^{-}$を $\xi$-平面上の単位円 の外部領域 $\Sigma^{-}$に写像する方法であり, それによって

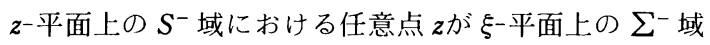

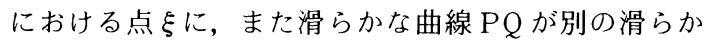
な曲線 $\mathrm{P}^{\prime} Q^{\prime}$ に完全に対応する. 式 (1) 中の関数 $\omega(\xi)$ が $S^{-}$域から $\Sigma^{-}$域への単値等角写像を決定するため, 等角写像関数とも呼ばれ, その逆写像関数 $\omega^{-1}(\xi)$ が存 在する.

この方法を適用するに際して, 孔の断面境界の形状を 正しく表せる写像関数が重要であり, 写像関数 $\omega(\xi)$ は, 単位円の外側または円周上での点 $\xi$ が, ただ 1 つの点 $z$ を写像するように選ばなくてはならない，そのために， Schwarz-Christoffel 変換 ${ }^{15)}$ を用いる必要がある.

\section{（2）空洞境界の写像関数}

地下岩盤空洞の断面形状は，特例を除いて，Fig.2に 示すように, 棈円形や矩形のような 2 軸対称亡馬蹄形の ような 1 軸対称に分けられる. Schwarz-Christoffel の 変換公式によれば，隅半径で直角部を丸めた矩形空洞を はじめ, 2 軸対称亡なる空洞の孔縁境界の写像関数 $\omega(\xi)$ は, 級数展開形で表すと, 次のようになる ${ }^{16)}$.

$$
z=A_{0}\left(\alpha_{0} \xi+\sum_{m=2}^{M} \alpha_{2 m-3} \xi^{3-2 m}\right)
$$

また，Y軸に関する 1 軸対称の場合は,

$$
z=A_{0}\left(\alpha_{0} \xi+\sum_{m=1}^{M} \alpha_{m} \xi^{-m}\right)
$$

ここに, $z=x+i y, \xi=\rho e^{i \theta}(\rho \geqq 1) ;(x, y)$ はデカルト 直角座標系; $(\rho, \theta)$ は直角曲線座標系である. $\rho=1$ は $z$-平面上の孔縁境界, $\rho>0$ はその外部領域に対応する ことになる. また, $A_{0}=2 \mathrm{a}$ (空洞の幅); $\alpha_{m}(m=1,2$, $\cdots, M)$ は空洞の孔緣形状によって決まる実定数; $M$ は 級数の打ち切り項数を表す. 空洞の断面が円形の場合は, $\alpha_{m}=0(\boldsymbol{m}=1,2, \cdots, \boldsymbol{M})$ 亡なり, 棈円形の場合では, $\alpha_{m}=0(m=2,3, \cdots, M)$ となる.

\section{（3）写像関数の係数の決定}

式（2）と（3）を展開し, 両辺の実数部と虚数部を それぞれ等置し, しかも $\rho=1$ とすれば, デカルト座標 系における空洞の孔縁境界の座標値 $\left(x_{i}, y_{i}\right)$ を定義す る以下に示す方程式組が得られる.

$$
\left.\begin{array}{c}
x_{i}=A_{0}\left[\alpha_{0} \cos \theta_{i}+\sum_{m=1}^{M} \alpha_{m} \cos \left(m \theta_{i}\right)\right] \\
y_{i}=A_{0}\left[\alpha_{0} \sin \theta_{i}-\sum_{m=1}^{M} \alpha_{m} \sin \left(m \theta_{i}\right)\right] \\
(i=1,2, \cdots, N)
\end{array}\right\}
$$

ただし，係数 $\alpha_{m}$ は 2 軸対称の場合において， $m$ が偶数 であればゼロとなる。係数 $\alpha_{m}$ は, 実際の空洞の孔縁境 界に若干の点 $i(i=1,2, \cdots, N)$ を選び, 式 (4) で定 義される曲線がこれら一連の点を通過するように決定さ れる. 式（4）において, $N$ 個の選点に対し $N$ 対の方 程式組（4）が得られるが, Fig.2に示すように, 図形 の対称性から, 2 軸対称の場合は空洞境界の $1 / 4$ 範囲内 で $\theta_{1}=0, \theta_{N}=\pi / 2$, また 1 軸対称の場合は, 空洞境界 の $1 / 2$ 範囲内に $\theta_{1}=-\pi / 2, \theta_{N}=\pi / 2$ であることが分か る. 従って, 方程式組 $(4)$ は $\alpha_{1} \sim \alpha_{M}$ および $\theta_{2} \sim \theta_{N-1}$ を 未知数とする連立方程式組であり, それを解くに際して は, $N>M$ となるように選点すれば, 最小二乗法によっ て, 実際の空洞形状を精度よく表せる係数が決定できる.

\section{3. 円形空洞の弾塑性解}

ここに, 先に提案した円形空洞に関する弾塑性理論解 


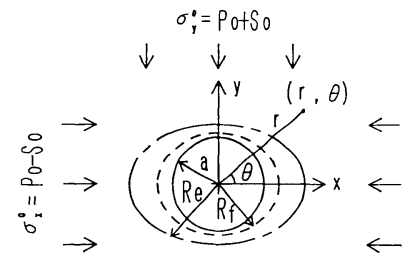

(a)

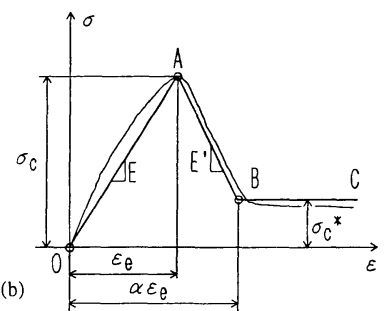

Fig.3 The problem of a circular opening under non-hydrostatic condition.

の概要を述べておく.

Fig.3に示すような 2 軸応力状態における円形空洞の 弾塑性問題については, 従来より多数検討されてきたが, その主要成果である塑性領域の規模を表わす塑性半径 は, 高次式であり, 数值的にしか解けないため, それら を直接写像変換させることは不可能である．著者らは同 じ問題に対し，塑性論と複素関数論に基づいた一般的な 解析解を導いている31.

周辺岩盤が, ピーク強度以降にひずみ軟化およびダイ レタンシー挙動を呈するとし, 応力ーひずみ関係として は, ひずみ軟化挙動を, ピーク強度 $\sigma_{c}$, 残留強度 $\sigma_{c}^{*}$ と ぜい性率 $\alpha$ によって評価する。 そして，ピーク強度 $\sigma_{c}$ から残留強度 $\sigma_{c}^{*}$ まで, ひずみとともに強度が線形的に 減少していくと仮定する。 ぜい性率 $\alpha$ は, 塑性流動状 態に入る直前の軸ひずみとピーク強度に対する軸ひずみ の比によって表されるが， $\alpha=0$ は完全弾ぜい性モデル を，また， $\alpha \longrightarrow \infty$ は完全弾塑性モデルを意味する，岩盤 材料の強度特性は, Mohr-Coulomb の破壊規準に従う ものとする. ただし, 残留強度は, その場の応力状態に おける内部粘着力と内部摩擦角で定められるものとす る. また, 岩盤が破壊後体積膨張（ダイレーション）を 起こすとする，塑性ポアソン比（最小主ひずみの塑性成 分と最大主ひずみの塑性成分との比と定義される）は, Mohr-Coulombの降伏関数を塑性ポテンシャル関数と して塑性流れ則に従えば，ダイレタンシー角 $\phi^{*}$ との関 係を求めることができる.

初期地山応力状態は, Fig.3 に示すように, $x$ 方向よ $y$ 方向の初期地山応力成分をそれぞれ $P_{0}$ と $S_{0}$ に分解す る.ただし， $P_{0}$ は静水圧に相当し， $S_{0}$ は初期応力の偏 差部分である，解析では，岩盤の自重が無視される.
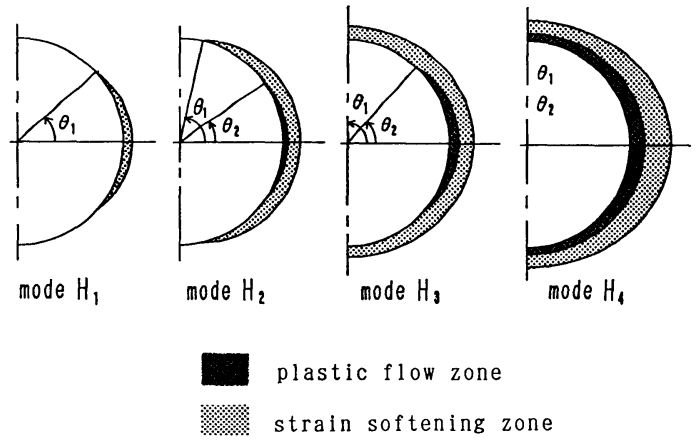

Fig.4 Classification of the failure modes around an unsupported openinig.

Table 1 Classification of the failure modes.

\begin{tabular}{|c|c|c|c|}
\hline$モ-ト ゙$ & $\begin{array}{l}\text { 塑性半径 } \\
(\theta=0 \text { 上 })\end{array}$ & 望性角 & 望性破堘モードの特徽 \\
\hline $\mathrm{H}_{1}$ & $R_{\bullet} \geqq a>R_{f}$ & $0 \leqq \theta_{1}<90^{\circ}$ & $\begin{array}{l}\text { 内空壁面が部分的に塑性化され, } \\
\text { 周辺には,ひずみ顿化のみが, } \\
\text { 最小地山场方方向に進展する。 }\end{array}$ \\
\hline $\mathrm{H}_{2}$ & $R_{e}>R_{1} \geqq a$ & $\theta_{2}<\theta_{1}<90^{\circ}$ & $\begin{array}{l}\text { 内空壁面が部分的に塑性化される } \\
\text { が、最小地山店力方向に真する } \\
\text { 壁面には塑性流動破塿が発生する。 }\end{array}$ \\
\hline $\mathrm{H}_{3}$ & $R_{e}>R_{f}>a$ & $\theta_{2}<\theta_{1}=90^{\circ}$ & $\begin{array}{l}\text { 壁面全周が盟性化される。塑性流 } \\
\text { 動域が, 最小地山応力方向に部分 } \\
\text { 的に深部に匝がっていく。 }\end{array}$ \\
\hline $\mathrm{H}$. & $R_{\bullet}>R_{f}>a$ & $\theta_{2}=\theta_{1}=90^{\circ}$ & 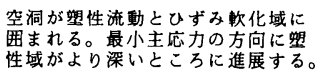 \\
\hline
\end{tabular}

先に述べた応力ーひずみの定式化に基づくと，空洞の 周辺岩盤には, 塑性流動領域, ひずみ軟化領域と弾性領 域が生じられる.また, 空洞の内空壁面が完全に塑性化 されるかまたは部分的に塑性化されることや塑性流動領 域の有無を考慮すれば, Fig.4 に示すような4つの塑性 破壊モ一ド $\left(H_{1} \sim H_{4}\right)$ が考えられる. 各々の塑性破壊モ一 ドが塑性半径 $\left(R_{e}, R_{f}\right)$ と塑性角 $\left(\theta_{1}, \theta_{2} ; 0 \leqq \theta_{2} \leqq \theta_{1} \leqq 90^{\circ}\right)$ によって定義される. Table 1 には, 各塑性破壊モ一ド の定義とその特徵を示してある. 弾塑性境界の円周上の 境界角 $\theta_{1}$ 之塑性流動領域の円周上の境界角 $\theta_{2}$ の決定方 法は文献 3）に詳述している.2つの塑性半径の解析式 をまとめて示すと以下のようになる.

\section{(1) $0 \leqq \theta \leqq \theta_{2}$ の範囲}

この範囲では, 空洞の内空壁面が塑性流動を生じるた め, 2つの塑性半径が次のようになる.

$$
\begin{aligned}
& R_{e}=\left(\frac{D_{1}+D_{2} \xi^{1-K_{p}}}{\sigma_{c}^{*} /\left(K_{p}-1\right)}\right)^{\frac{1}{K_{p}-1}} \\
& R_{f}=\zeta R_{e}
\end{aligned}
$$

上式中, $R_{e}$ は弾塑性境界の半径, $R_{f}$ は塑性流動領域の

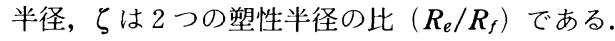

\section{( 2 ） $\theta_{2} \leqq \theta \leqq \theta_{1}$ の範囲}

内空壁面が塑性流動を発生せず，ひずみ軟化状態にあ 
るため, $R_{f}<a$ となり, $R_{e}$ が次の方程式を満足するよ うに求められる.

$$
F\left(R_{e}\right)=F_{1}-D_{1} R_{e}^{1-K_{p}}=0
$$

ただし， $K_{p}$ は内部摩擦角による強度係数で, パラメ一 夕 $D_{1}, D_{2}, F_{1}$ は力学的物性値による係数である ${ }^{1), 21}$.

\section{( 3 ） $\theta_{1} \leqq \theta \leqq 90^{\circ}$ の範囲}

この範囲では，内空壁面が塑性破壊を発生せず，弾性 状態にある。

\section{4. 写像解析に基づく塑性領域の推定法}

等角写像展開原理は, $z$-平面上の非円形孔境界および その外部領域を $\xi$-平面上の単位冈およびその外部領域 に写像するのに用いられる.ここに示す写像解析に基づ く塑性領域の推定法は, 空洞孔縁の写像関数 $\omega(\xi)$ と 関係付ける逆写像関数 $\omega_{1}^{-1}(\xi)$ を用いることにより， $\xi$ 平面上の単位円孔周辺に生じる弾塑性境界 $\Gamma\left(R_{e}\right)$ を,

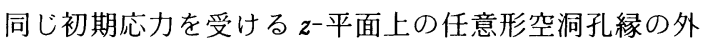
部に等角変換させる方法である. $\omega_{1}^{-1}(\xi)$ は正則関数で ある. 写像関数 $z=\omega(\xi)$ は正則関数であるため, その 逆問題, すなわち, $\xi$-平面上の領域を $z^{-}$平面上に逆写 像することももちろん可能である. さて， $\boldsymbol{z}$-平面上に, $\xi$-平面上と同じ原点を持つように空洞孔縁と塑性領域の 境界面を同時に写像するために, 両写像関数の間には近 似的に次式のような関係がある ${ }^{17)}$.

$$
\omega_{1}(\xi) \fallingdotseq G_{c} R(\xi) \omega(\xi) ; R(\xi)=\left\{R_{e}, R_{f}\right\}
$$

ここで, $G_{c}$ は地山の力学特性值による正の係数である. 塑性領域の境界線の写像関数 $\omega_{1}(\xi)$ が $\omega(\xi)$ と同じ形 を近似的に持つと考えられる.

さて, 任意形空洞のまわりの塑性領域を写像解析的に 推定する具体的な手順を以下に説明する (Fig.5 参照).

1) 与えられた地山条件での単位円孔の弾塑性解析を 行い, 塑性領域が発生するかどうかを判定する. 塑性領 域が発生する場合, 式（5）と（6）に上り, 各計算角 $\theta$ に対する塑性半径 $R_{e}, R_{f}$ を計算する.

2) 非円形空洞の孔縁境界の写像関数を式( 2$) \sim(4)$ によって求める.

3） 2 つの塑性領域の境界を, 写像関数 $\omega_{1}(\xi)$ を用 いて, 同平面上の非円形空洞周りに写像する.つまり塑 性半径 $R_{e}, R_{f}$ を式 ( 4 ) の $A_{0}$ に置き換えて座標值 $\left(x_{i}\right.$, $\left.y_{i}\right)$ を計算する. なお，係数 $\alpha_{m}(m=0,1, \cdots, M)$ は非 円形空洞の孔縁境界の写像関数の係数を用いる.

4) 計算角 $\theta$ に対して求まった座標値 $\left(x_{i}, y_{i}\right)$ を順 番につなげば, 非円形空洞周りに生じる塑性領域の境界 線となる.

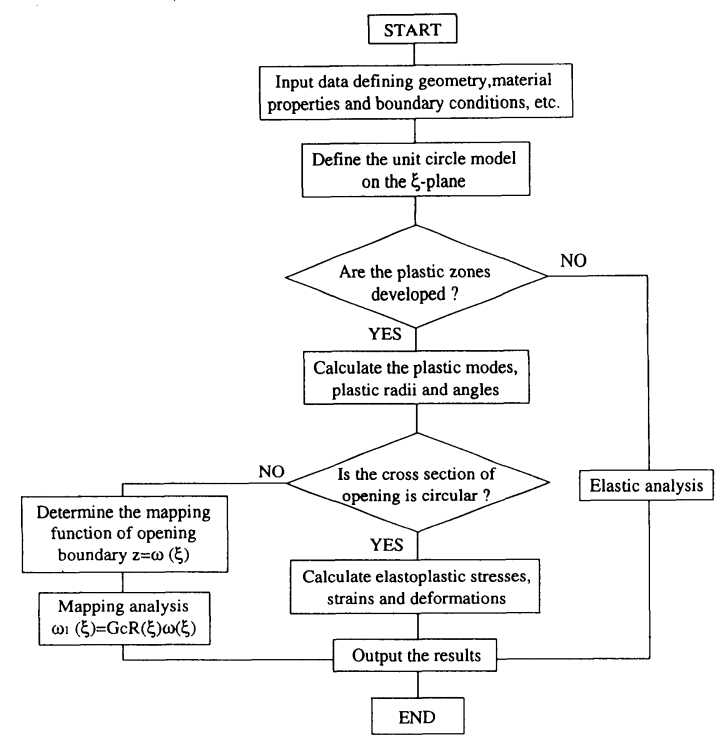

Fig.5 Flow chart for mapping analysis method.

\section{FEM 数值解析による検証と考察}

\section{（1）はじめに}

空洞壁面付近の応力の集中度や方向は, 空洞の断面形 状に大いに影響されるものである。 また，式（7）に現 れた係数 $G_{c}$ は, 弾塑性境界面において必ずしも一定で ないため, 塑性領域の広がりが, 空洞孔縁境界の写像関 数と同じスケールで深部に延びていくわけではない.こ こで簡便のために, 係数 $G_{c}$ を 1 とし, 円形, 正方形, 長方形および馬蹄形, という4 種類の典型的な断面形状 について写像解析を行い, FEM (有限要素法) 弾塑性 解析との比較により, その妥当性を確認する. 解析プロ グラムは MARC/MENTATを使用し，4節点アイソパ ラメトリック要素でモデル化した．破壊規準としては線 形モール・クーロンの破壊基準を用いた。

岩盤の物性値は, ヤング率 $E=1.5 \mathrm{GPa}$, ポアソン比 $\mu=0.25$, 圧縮強度 $\sigma=0.5 \mathrm{MPa}$, 内部摩擦角 $\phi=30^{\circ}$, ダイレタンシー角 $\phi^{*}=20^{\circ}$ とし, また, 岩盤は弾性完 全塑性体と仮定している. 初期応力の載荷状態は, 静水 王状態 $\left(P_{0}=1.0 \mathrm{MPa}, S_{0}=0.0 \mathrm{MPa}\right)$ と非静水圧状態 (側圧係数 $k=0.5$, すなわち, $P_{0}=0.75 \mathrm{MPa}, S_{0}=$ $0.25 \mathrm{MPa})$ に分けた。塑性領域の範囲は等価塑性ひず みコンター分布によって定められた。

\section{（2）解析結果の考察}

Fig.6は, 両解析手法による解析結果の対比図で, 実線 は写像解析による推定結果, 点線はFEMによる計算 結果, また, 対称軸の左に静水圧状態を, 右に側圧係数が $k=0.5$ の場合の弾塑性境界線をそれぞれ示してある. 


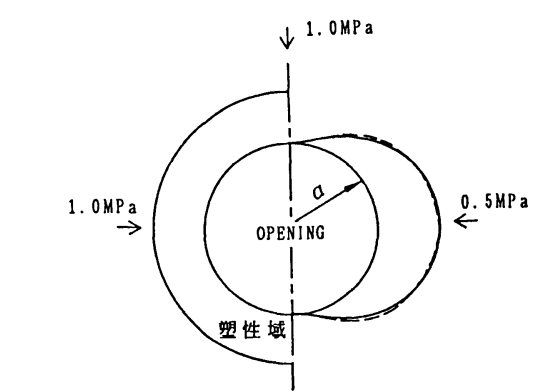

(a ) 円形

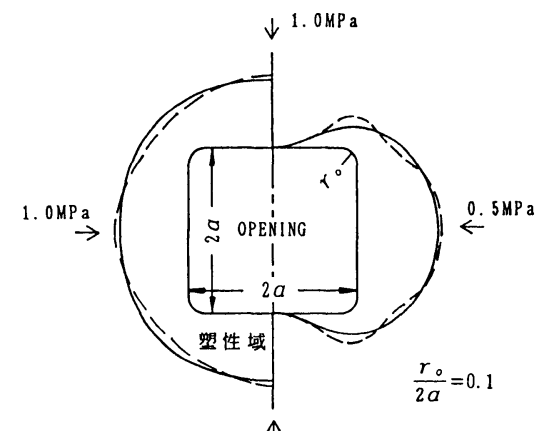

( b ) 正方形

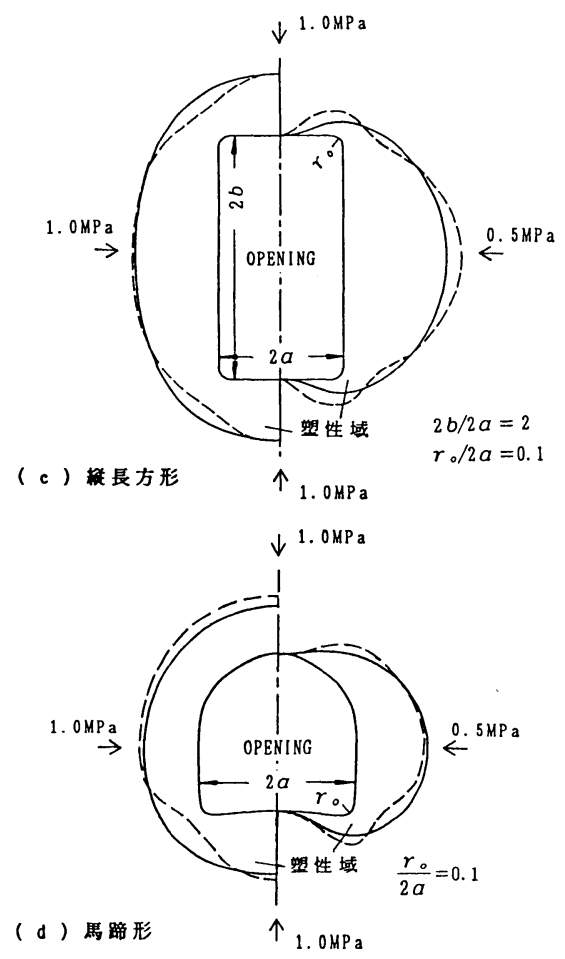

Fig.6 Comparisons of the plastic areas analyzed by the mapping analysis method(solid lines) and FEM(broken lines).

円形空洞を見てみると塑性境界に関する本手法の結果 は, FEM の解析結果とよく一致していることが分かる. 他方, 空洞の断面形状が正方形の場合は, 隅角半径比

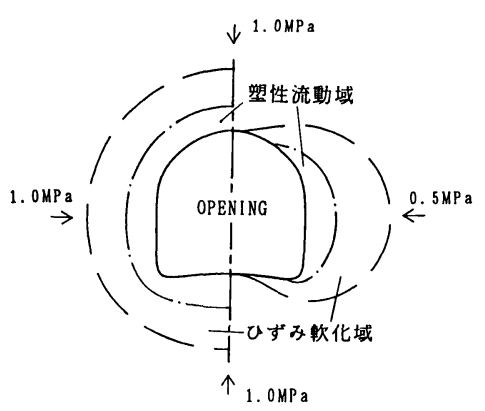

Fig.7 Application of the proposed method to the strainsoftening model.

$\left(\gamma_{0} / 2 a\right)$ を0.1 とした。解析結果の比較は Fig.6 ( b ) に示すように，隅角部では，応力の方向や大きさが急に 変化するため, 写像解析法による推定結果と, FEM の 解析結果との間には幾分差異が見られているが，全体的 にはほぼ一致していることが分かる。

また，縦長長方形断面の場合は，縦方向と横方向の形 状比(空洞の高さ $2 \mathrm{~b} /$ 幅 $2 \mathrm{a}$ )を 2 とし, 隅角半径比を 0.1 と仮定した．正方形の場合と比較すれば，縦横の形状比 が倍に挔大したため，空洞壁面の中央部では両者の差異 がやや大きくなり, 非静水圧状態において, 両者の誤差 が一部 $8 \%$ に達したが，他はほぼ $5 \%$ 以内に収まってい る (Fig.6 ( c )).

さらに, 馬蹄形断面の場合は, 静水圧状態においては, 空洞の上半部に発生する塑性領域が若干小さく写像され ている.これは, 入力の簡略化のため, FEM 解析モデ ルでは空洞の上半部を半円形，下半部を横長方形と近似 して，孔縁境界を入力したので，写像された実線の馬蹄 形状と多少異なっているためと考える（Fig.6（d）).

以上の比較により, 写像解析推定法は, FEM 解析結 果とよい一致性を示し，岩盤空洞の周辺に発生する塑性 領域の大きさを比較的精度よく，しかも簡便に評価でき ることが確認された。

\section{（3）ひずみ軟化モデルへの適用}

以上は, 弾性完全塑性モデルについて, 比較的解析を 行って，よい一致性が分かったが，つぎにひずみ軟化モ デルへの適用性を考察する.

Fig.7 は, Fig.6 (d ) と同じ初期応力条件で,ひずみ 軟化モデル（残留強度比 $\sigma_{c}^{*} / \sigma_{c}=0.6$, ぜい性率 $\alpha=2$ ) を用いて写像解析した例である. 破線は弾塑性境界を, 一点鎖線は塑性流動領域の境界を表している，最小主応 力に垂直な空洞の両側壁において塑性流動領域が発生し た. Fig.6 ( d ) と比較してみると, 空洞まわりの塑性 領域の規模は, 周辺地山が破壊後のひずみ軟化挙動に支 配され，その結果，塑性領域が広がり，その中にひずみ 軟化領域と塑性流動領域が含まれている. 


\section{6. おわりに}

掘削による空洞周辺地山の塑性破壊の判断およびその 広がりの解明は, 地下空洞の位置, 支保工荷重と覆工厚 さ,ロックボルトを事前設計する上で非常に重要である. 本研究は非円形地下空洞の安定評価を行うための 1 つの 簡易手法として, 写像解析法を提案した。 その特徴は, 複素関数論における等角写像展開法に基づき, 空洞孔縁 境界の写像関数さえ求めれば, その周辺地山の塑性領域 の広がりを単位円孔の理論解より直接に逆写像解析する ことにより評価することができるものである.

この手法を用いて解析した結果を, FEMによる数值 シミュレーションと比較検証したところ, 空洞孔縁の隅 角のところで弾塑性解析法の結果とは幾分異なるが，全 体は両者がよく一致しており, 空洞安定性を精度よく評 価できることが判明された。 また，この手法は，完全弾 塑性モデルにのみならず，ひずみ軟化弾塑性モデルにも 適用することができた。

本手法は, 煩雑な弾塑性解析が要らず, 一般のパソコ ン上でも簡便に実行できる特徵を有するため, 実用性が 大きいと考える．本論文は，Fig.4に示した 4 つの塑性 領域モ一ドが発生する場合についてのみその結果を示し たが，初期地山の応力状態によってはそれ以外の塑性 モードの発生が考えられるので, そのような場合への適 用や, 種々の断面形状の空洞を取り巻く塑性領域境界の 写像関数をより正しく求めることによって, 塑性領域の 写像精度を上げることは今後の課題としたい.

\section{参考文献}

1) Esaki T. and Jiang Y.J. : Stability analysis of a deep tunnel with the elasto-plastic strain softening behavior, Proc. 7 th Int. Conf. on Computer Method and Advcances in Geomechanics, pp.1467-1472, 1991.

2) 蔣宇静, 江崎哲郎, 横田康行 : 軟岩トンネル周辺岩盤安 定機構とその設計について, 土木学会トンネル工学研究 発表会論文報告集, Vol. 3, pp. 17-24, 1993.

3）江崎哲郎, 蔣宇静：ひすみ軟化およびダイレタンシー特 性を考虑した非静水圧状態における空洞周りの岩盤举動
の解析法, 土木学会論文集, 第 481 号 $/$ III -25, pp.41-48, 1993.

4） Kastner, H. : トンネルの力学, 森北出版, 1974.

5) Einstein, H. and Schwartz, W. : Simplified analysis for tunnel supports, ASCE, 1979.

6） Egger, P.：海峡連絡鉄道の技術に関する文献資料調査報 告書, 日本トンネル技術協会, 1979 .

7) Brown, T. and Bray, J.W. : Ground curves for rock tunnels, J. Geotech. Eng. Div., ASCE, Vol.109, No.1, pp.15-39, 1983.

8) Detournay, E. and Fairhurst, C. : Two-dimensional elasto-plastic analysis of a long, cylindrical cavity under non-hydrostatic loading, Int. J. Rock Mech. Min. Sci. \& Geomech. Abstr. Vol.24, No.4, pp.197-211, 1987.

9）杉本三隆，松本嘉司，金沢芳信：エネルギー論に基づく 棈円トンネルの安定解析, 土木学会論文集, 第 424 号 / III-14, pp. 197-205, 1990.

10）青木俊朗, 菅原勝彦: 2 軸応力下の連接円形空洞および 単設矩形空洞の弾塑性解析, 資源, 素材学会誌, No.7, pp. 511-516, 1989.

11) Stacey, T.R. :A simple extension strain criterion for fracture of brittle rock, Int. J. Rock Mech. Min. Sci. \& Geomech. Abstr., Vol.18, pp.469-474, 1981.

12) Waldeck, H.G. : The design and support of large underground chambers at depth in gold mines of the Gold Fields Group of South Africa, Proc. 4 th Int. Congr. ISRM, Montreux, Vol.1, pp.565-571, 1979.

13）桜井他：計測変位に基づく地下空洞周辺地山に発生する 塑性領域の推定法, 土木学会論文集, 第 394 号 $/$ III -9 , pp. 89-96, 1988.

14）例えば, 北川英夫, 結城良治：二次元応力状態における 分岐き裂の応力拡大係数, 日本機械学会論文集, 41-346, pp. 1641-1649, 1975.

15) Timoshenko S. and Goodier, J.N. : Theory of Elasticity, McGRAW Hill, New York, 1951.

16) S.R. Heller, Jr., et al. : The stresses around a rectangular opening with rounded corners in a uniformly loaded plate, Proc. 3 rd US. Natl. Cong. Appl. Mech., pp.357-368, 1958.

17) 蔣 宇静: 樑部地下空洞の力学的安定に関する理論的お よび実験的研究, 九州大学学位論文, 1993.

18) Derski, W., et al. : Rock and soil mechanics, PWN, Warsaw, 1989.

(1994.8.1 受付)

\title{
A MAPPING METHOD FOR THE PREDICTION OF PLASTIC ZONE AROUND NON-CIRCULAR UNDERGROUND OPENINGS
}

\author{
Yujing JIANG and Tetsuro ESAKI
}

\begin{abstract}
To predict the plastic zone around non-circular cross-section openings under biaxial stress field usually one has to use a numerical analysis method such as FEM(finite element method), etc. As a simple and convenient method, the mapping method used to evaluate the plastic zone around the non-circular openings is put forward in this paper, based on the principle of mapping function method and the theoretical solutions for the circular opening with the advantage of considering the strain softening and volume dilation after rock failure (Esaki, T., et al., 1993). Computer simulations of the plastic zones using the FEM are carried out in order to prove this proposed mapping method. The method can be applied to not only the perfectly elasto-plastic model but also the strain softening model. With the advantage of avoiding the complicated elasto-plastic analysis and being used on a personal computer, this method is very useful.
\end{abstract}

